\title{
NOD2/CARD 15 gene mutations in patients with Familial Mediterranean Fever
}

\author{
Y Berkun*, A Karban, S Padeh, Y Shinar, E Pras, M Lidar, A Livneh, Y Bujanover \\ From 18th Pediatric Rheumatology European Society (PReS) Congress \\ Bruges, Belgium. 14-18 September 2011
}

\section{Background}

Familial Mediterranean fever (FMF) and Crohn's disease (CD) are autoinflammatory disorders, associated with genes (MEFV and NOD2/CARD15), encoding for regulatory proteins, important in innate immunity, apoptosis, cytokine processing and inflammation. While mutations in the MEFV gene were shown to modify $C D$, the role of NOD2/CARD 15 gene mutations in the FMF disease phenotype was never studied before.

\section{Methods}

The cohort consisted of 103 consecutive children with FMF, followed in a single referral center. NOD2/ CARD15 genotypes were analyzed in all patients and 299 ethnically matched unaffected controls. Demographic data, clinical characteristics and disease course of FMF patients with and without NOD2/CARD 15 mutation were compared.

\section{Results}

A single NOD2/CARD 15 mutation was detected in 10 (9.7\%) FMF patients and $26(8.7 \%)$ of controls. No homozygotes or compound heterozygotes were discovered in the 2 groups. FMF patients carrying a NOD2/ CARD 15 mutation had higher rate of erysipelas-like erythema and acute scrotum attacks and a trend for higher rate of colchicine resistence and a more severe disease as compared to patients without mutations.

\section{Conclusion}

NOD2/CARD 15 mutations are not associated with a susceptibility to develop FMF, yet the presence of these

Department of Pediatrics A and Pediatric Rheumatology, Edmond \& Lily Safra Children's Hospital, Chaim Sheba Medical Center, Tel Hashomer, Sackler School of Medicine, Tel Aviv University, Tel Aviv, Israel mutations in FMF patients appears to be associated with a trend to a more severe disease.

Published: 14 September 2011

doi:10.1186/1546-0096-9-S1-P291

Cite this article as: Berkun et al: NOD2/CARD 15 gene mutations in patients with Familial Mediterranean Fever. Pediatric Rheumatology 2011 9(Suppl 1):P291.
Submit your next manuscript to BioMed Central and take full advantage of:

- Convenient online submission

- Thorough peer review

- No space constraints or color figure charges

- Immediate publication on acceptance

- Inclusion in PubMed, CAS, Scopus and Google Scholar

- Research which is freely available for redistribution

\section{() Biomed Central}

\section{Biomed Central}

